\title{
Factors that influence students' learning progress in the science spiral progression curriculum
}

\author{
Rizaldy E. Garcia*
}

* Rizal Technological University, College of Education, Mandaluyong City, Philippines Email: regarcia@rtu.edu.ph

\section{Article Info}

Received: June 9, 2020

Revised: July 18, 2020

Accepted: July 26, 2020

\section{$10.46303 / j c s r .2020 .5$}

\section{How to cite}

Garcia, R.E. (2021). Factors that influence students' learning progress in the science spiral progression curriculum. Journal of Curriculum Studies Research, 3(2), 79-99. https://doi.org/10.46303/jcsr.2020.5

\section{Copyright license}

This is an Open Access article distributed under the terms of the Creative Commons Attribution 4.0 International license. https://creativecommons.org/licenses/by/4.0/

\begin{abstract}
The study delved into the factors that influence students' learning progress in the implementation of the science spiral progression curriculum in selected public junior high schools in the Division of Pasig City, Philippines, covering the school year 2017 - 2018. The study used the quantitative approach to research, particularly the descriptive research methodology. The specific descriptive research design utilized was normative survey. Data were statistically tested with the use of frequency distribution formula, percentage formula, and weighted mean. The study concluded that the perspectives of the science teachers in executing the science spiral progression curriculum vary from school to school. The study also found out that several factors influence the students' learning progress and that majority of the Grade 10 students for the School Year 2017 - 2018 of the Division of Pasig City Philippines have "fairly satisfactory" performance. KEYWORDS

Teacher education; science education; science curriculum; science teaching; spiral progression.
\end{abstract}




\section{INTRODUCTION}

The old basic education curriculum of the Philippines mandates that Filipino learners should finish their schooling for ten years. This is 6 years of primary school and 4 years of secondary school. Primary school is composed of grades 1 to 6 , while secondary schooling is composed of 1st year to 4th year. Kindergarten is also not mandatory. The Philippines' Department of Education in the time of the then-president Benigno $C$. Aquino pushed for the amendments of the basic education curriculum. The president and the department envisioned a 12-year basic education curriculum in addition to a mandatory Kindergarten, hence the birth of the $\mathrm{K}$ to 12 basic education curricula in the Philippines.

The implementation of the new $\mathrm{K}$ to 12 basic education curricula in the Philippines started in the school year 2012-2013. Preceding this, the Kindergarten Act was implemented in the school year 2011-2012 under Republic Act 10157. With its implementation, a paradigm shift in the basic education system had been implemented. One feature that had changed is the structure of the curriculum. In the area of science, especially in the junior high school level, the spiral progression curriculum has been adopted. This curriculum deviated from the usual practice in which in each grade level, there is a specialized science subject. For instance, the 1styear level will take integrated science, the 2nd-year level will take biology, the 3rd-year level will take chemistry and the 4th-year level will take physics. In the case of the new curriculum, the specialized subjects are merged into one level. This means that in each grade level, students will take the four basic science disciplines, namely Earth Science, Biology, Chemistry, and Physics in a spiral progression manner. The basic concept of this curriculum is to highlight the understanding and application of scientific knowledge, learning scientific inquiry skills, and developing and demonstrating scientific attitudes and beliefs (Science Framework for Philippine Basic Education: DOST, 2011).

A spiral progression is an approach that follows the progressive type of curriculum. The approach was anchored from John Dewey's total learning experiences of an individual. Martin (2008) defined progression as a thing that labels pupils' flights through education and ways, in which they acquire, apply, develop their skills, knowledge, and understanding in increasingly challenging situations. Based on this approach, the $\mathrm{K}$ to 12 science spiral progression approach was implemented to utilize a learner-centered approach such as inquiry-based learning pedagogy. The K to 12 Curriculum Guide of Science (2013), stated that the goal of the science curriculum is to produce scientifically literate citizens who are informed and active participants of the society, responsible decision-makers, and apply scientific knowledge that will significantly impact the society and the environment.

The research is based on three theoretical lenses namely, constructivism, progressivism, and social reconstructionism (Mauch \& Tarman, 2016). According to Elliot et al. (2000), constructivism is a learning approach that holds that learners' construct knowledge based on their past experiences. Its focus is on the idea that human learning is constructed, that learners build knowledge upon the foundation of previous learning to influence his/her new knowledge (Phillips, 1995). The Philippine $\mathrm{K}$ to 12 curricula as a curriculum embraces the idea of constructivism. Learners in this curriculum use spiral progression which means that concepts are taught early and then being retaught in succeeding years but with increased sophistication and complexity. Also, learners continuously reflect on their experiences while developing the needed abilities and skills to achieve learning. 
John Dewey's progressivism, on the other hand, talks about individuality, progress, and change as fundamental aspects to one's education, Labaree (2000), said that progressivism is a child-centered instruction (Mason, 2019). He said that all that is accomplished in the classroom is accomplished to assist and foster the student's development, which is also based on the developmental task of the learners and that learning is constructed based on discovery and experience. In the Philippine $\mathrm{K}$ to 12 curricula, the curriculum aims to improve learners who are equipped with adequate proficiencies which could be attained by keenly utilizing and employing it in the actual world. Also, in the current Philippine $\mathrm{K}$ to 12 curriculum learners are to experience the world; it is, therefore, active not passive in its nature.

Brameld (1956) stated that reconstructionism is a philosophy that underscores the tackling of social questions and the pursuit to establish a better society and global democracy. On the current Philippine $\mathrm{K}$ to 12 curricula, its goals underline on social reform, which is from a 10 -year basic education to a 12-year plan. The traditional perception that a 10 - year basic education is adequate has been transformed to enhance human conditions and will let the students experience and take a social action on real problems.

When the Philippines' Department of Education implemented the said curricula, it demanded a lot from the teachers. Science teachers cannot escape this new challenge because the basic concept of this curriculum is to emphasize the understanding and application of scientific knowledge, learning scientific inquiry skills, and developing and demonstrating scientific attitudes and beliefs (Science Framework for Philippine Basic Education: DOST, 2011). Studies have shown that 'teacher quality' is the single most important school-level variable influencing student achievement (OECD, 2005). A review of 20 high-quality studies measuring the impact of teacher quality in developing countries found that teachers when subjected to knowledge training was strongly related to student learning (Glewwe, Hanushek, Humpage \& Ravina, 2011). Colclough (2005) said the importance of teachers to student outcomes has resulted in a shift in aid investment from a primary focus on increasing access to education to increasing support for interventions aimed at improving teacher quality in developing countries.

Burila (2012) wrote that concerns have been raised in the communities where poverty is prevalent that the $\mathrm{K}$ to 12 curricula will not be viable because of some concerns such as availability of technology, teachers training, and even salary of the workforce. Since its implementation in the School Year 2012-2013, the first batch of graduates had walked on the stage in 2018. Hence, this is the best time to assess the curriculum. It is a time to know the factors that influenced learning progress and to know whether the Science teachers make the best out of the new curriculum to teach their students.

\section{RESEARCH QUESTIONS}

The purpose of the research was to look into the factors that influence student's learning progress and to know the teachers' perspective on the implementation of the Science spiral curriculum in the selected public junior high schools in the Division of Pasig City, Philippines during the school year 2017 - 2018. Specifically, the study sought to find answers to the following research problems:

1. What is the perspective of the science teachers when executing the new science spiral progression curriculum?

2. What is the progress of the students as measured by their grade 10 individual grade average in science for the school year 2017 - 2018? 
3. What are the factors that greatly influence students' progress in the science spiral progression curriculum as to:

3.1 Student Factor:
a. Learning Style;
b. Study Habits; and
c. Motivation to Learn.

3.2 Teacher Factor:

a. Teacher's Specialization;

b. Teacher Training; and

c. Teaching Style;

3.3 School Factor:
a. School Facilities;
b. Learning Materials; and
c. Support to Teacher Training.

\section{CONCEPTUAL FRAMEWORK}

The conceptual framework as shown in this research illustrates the processes that were undertaken in the conduct of this study. The framework explains that there is a great deal of connection between science teachers and the students. This connection is signified and carried out in the execution of the science spiral progression curriculum.

In the execution of the curriculum, the teacher and the students will encounter factors that can affect students' progress. The factors that could influence these outcomes may come from the teacher themselves, the students, and the schools. To facilitate and to take advantage of these factors, a thorough study should be done to facilitate which of the factors that influence students' progress the most.

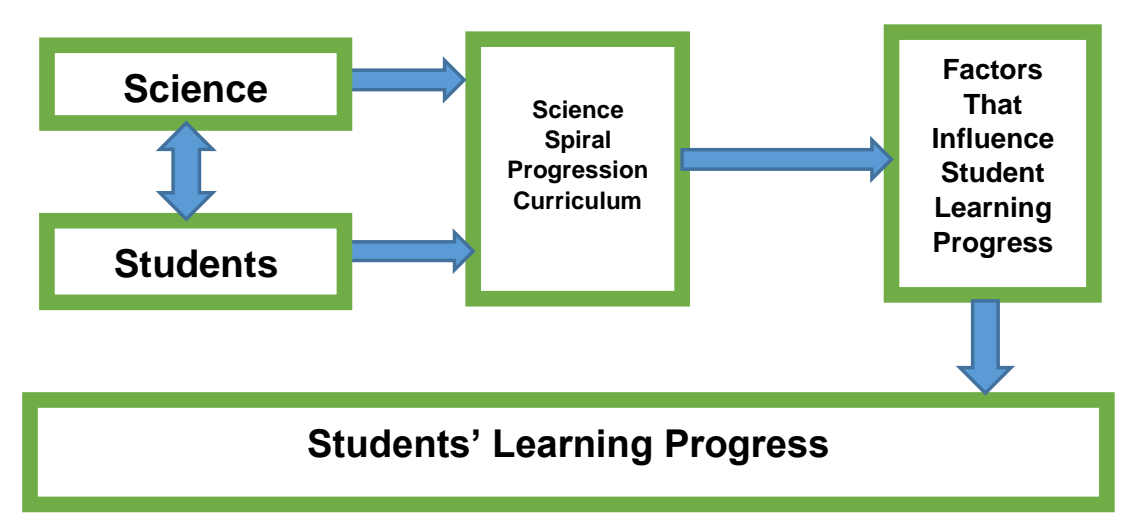

Figure 1. Conceptual Model

\section{RESEARCH METHODS AND DESIGNS}

This research used the quantitative approach as it delved with numerical data relative to the subject of the investigation. Hunter and Leahey (2008) defined quantitative research as the systematic empirical investigation of social phenomena via statistical, mathematical, or computational techniques. The specific research methodology utilized was descriptive research. This type of research involves either identifying characteristics of an observed phenomenon or exploring possible correlations among two or more phenomena. 
In every case, descriptive research examines a situation as it is (Leedy \& Ormrod, 2014). In this research, the descriptive delves into situations or conditions about the $\mathrm{K}$ to 12 science spiral progression curriculum through its normative survey design and contextual analysis techniques. The normative survey design describes and interprets "what is" and reveals conditions that exist, practices that prevail or do not prevail, and in attitudes that are held on or not (Estolas \& Macaballug, 1995). This design was used in this study to generate data on the perceptions of teachers on their execution of the science spiral progression curriculum, on how they handle the progression on factors that influence students' learning outcomes in the spiral progression curriculum and on how they describe themselves in selected personal characteristics.

A total of 195 science teachers were asked to answer the survey questionnaire. The purposive sampling was used to intentionally select individuals and sites to learn and understand the central phenomenon (Creswell, 2012). The same sampling scheme and standard were applied to the selection of the ten public junior high schools of the Division of Pasig City in the National Capital Region. The ten school participants represented 83.33 percent of the 12 public junior high schools in the Division of Pasig City. The science teachers who participated provided the necessary information required by the study. They were considered as "information-rich". More than 50.0 percent of the grade 10 students from each school were likewise purposively selected to elicit information on the progress of the students in the science spiral progression curriculum. Their science grade averages based on Report Cards and Grading Sheets were used in the study. The sample for each group was very adequate as shown by the sample percentages of more than 50.0 percent for each study population.

The research instrument used in this study is a modified instrument. The instrument was based on the "A Manual for the Use of the Motivated Strategies for Learning Questionnaires" by Paul R. Pintrich, David A.F. Smith, Teresa Garcia, and Wilbert J. McKeachie which was published by "The Regents of the University of Michigan" in 1991. The researcher devised the instrument in relation to the said questionnaire, with modification to suit the local setting in the Philippines, hence it is called a modified instrument. The validation process includes judgments by experts and pilot testing or dry run. The draft of the instrument was shown to the experts. Comments and suggestions were then incorporated in the final draft of the instrument. To strengthen the content validity of the instrument, a dry run was conducted to 15 selected science teachers in a certain secondary public school in the Division of Pasig City, Philippines.

The modified instrument used in this research has two major parts. Part I was concerned with the perspective of the public junior high school science teachers in executing the science spiral progression curriculum and it is composed of 15 item questions. Part II of the instrument gathered information on the factors that influence students' learning outcomes in the spiral progression curriculum in terms of student factor, teacher factor, and school factor. This part of the instrument is composed of 83 item questions distributed across the three variables namely, student factor, teacher factor, and school factor.

The behaviors measured by the instrument are the students' learning style, study habits, students' motivation to learn, and teachers' teaching style. The arbitrary ratings of the instrument are as follow:
Scale Value
$3.26-4.00$
$2.51-3.25$
$1.76-2.50$
$1.00-1.75$

\author{
Verbal Interpretation \\ Strongly Agree (SA) \\ Agree (A) \\ Disagree (DA) \\ Strongly Disagree (SDA)
}


The report cards and the grading sheets were used to get the grade averages of the student respondents. The researcher compared the report cards with the grading sheets to check the accuracy of the data. The description, grading scale, and remarks of the grades are shown in table 1.

Table 1: Description, Grading Scale and Remarks of the Grades

\begin{tabular}{|l|l|l|}
\hline Description & Grading Scale & Remarks \\
\hline Outstanding & $90-100$ & Passed \\
\hline Very Satisfactory & $85-89$ & Passed \\
\hline Satisfactory & $80-84$ & Passed \\
\hline Fairly Satisfactory & $75-79$ & Passed \\
\hline $\begin{array}{l}\text { Did Not Meet } \\
\text { Expectations }\end{array}$ & $74-$ below & Failed \\
\hline
\end{tabular}

Reference: Department of Education Order No. 8 Series of 2015, "Policy Guidelines on Classroom Assessment for the K to 12 Basic Education Program.

\section{DATA ANALYSIS}

The data gathered in this research were analyzed through descriptive statistical analysis. Specifically, this research utilized the weighted mean, percentage and frequency distribution, and Likert scaling. The weighted mean was used to compute the mean in the items presented in the instruments used. Each computed weighted mean was then traced to the Likert scaling with the corresponding verbal interpretation shown also in this research. The results were then interpreted and were intertwined with previous literature.

\section{RESULTS AND DISCUSSION}

\section{What are the perspectives of the science teachers when executing the Science Spiral Progression Curriculum?}

The table below shows the science teachers' perspectives when executing the science spiral progression curriculum in the Division of Pasig City, Philippines, the school year 2017-2018. The table conveys the weighted mean and its verbal interpretation for each item presented to the science teachers during the survey.

Based on the findings in table 2, the overall weighted mean for all the selected public junior high school in terms of their perspective when executing the science spiral progression curriculum is 2.84 with a verbal interpretation of "agree". This means that science teachers generally agree on the items presented to them in the survey. Analyzing the results deeper, with an overall weighted mean of $\mathbf{2 . 6 6}$ the science teachers agree that they have less likelihood to agree that they are given enough time to discuss the different topics in a school year while with an overall weighted mean of 3.23 , the science teachers have generally agreed that they have a 
good understanding on the content of the science spiral progression curriculum in terms of the knowledge, skills, and attitudes that my students should learn) got the highest.

Table 2: Weighted Means of the Perspectives of Science Teachers in Executing the Science Spiral Curriculum

\begin{tabular}{|c|c|c|}
\hline Items & $\begin{array}{c}\text { Weighted } \\
\text { Mean }\end{array}$ & $\begin{array}{c}\text { Verbal } \\
\text { Interpretation }\end{array}$ \\
\hline $\begin{array}{l}\text { 1. I have a good understanding of the content of the science } \\
\text { spiral progression curriculum in terms of the knowledge, } \\
\text { skills, and attitudes that my students should learn. } \\
\text { 2. I have a positive attitude towards the implementation of } \\
\text { the science spiral progression curriculum. } \\
\text { 3. I'm provided with plenty of resource materials in the } \\
\text { execution of the science spiral progression curriculum. } \\
\text { 4. I have the opportunities to receive recent or up to date } \\
\text { curriculum professional support. } \\
\text { 5. I have a sound knowledge of strategies known to be } \\
\text { effective for the teaching of the new science spiral } \\
\text { progression curriculum. } \\
\text { 6. I'm not reluctant to execute the science spiral progression } \\
\text { curriculum even though some of the topics included in the } \\
\text { curriculum are not my area of specialization. } \\
\text { 7. I'm given enough time to discuss the different topics in a } \\
\text { school year. } \\
\text { 8. I'm provided with a sound understanding of the } \\
\text { alternative ways of teaching the science spiral progression } \\
\text { curriculum for the students to understand better the } \\
\text { scientific ideas included in the curriculum. } \\
\text { 9. I have a strong motivation to ensure that the topics in the } \\
\text { science spiral progression are taught clearly in my school. } \\
\text { 10. I have a strong conviction that the science spiral } \\
\text { progression curriculum is solid in bridging the gap of the } \\
\text { former congested science curriculum. } \\
\text { 11. I have the personal confidence and necessary skills to } \\
\text { execute the science spiral progression curriculum } \\
\text { competently. } \\
\text { 12. I'm provided with the opportunity to undertake } \\
\text { professional development to enhance my knowledge in } \\
\text { executing the science spiral progression curriculum. } \\
\text { 13. I have the confidence that the contents in the science } \\
\text { spiral progression curriculum are well organized. } \\
\text { 14. I'm supported by the administration in your efforts to } \\
\text { execute the science spiral progression curriculum. } \\
\text { 15. I'm provided with the necessary equipment to teach the } \\
\text { science spiral progression curriculum. }\end{array}$ & $\begin{array}{l}2.72 \\
2.84 \\
2.73\end{array}$ & $\begin{array}{l}\text { Agree } \\
\text { Agree } \\
\text { Agree } \\
\text { Agree } \\
\text { Agree } \\
\text { Agree } \\
\text { Agree }\end{array}$ \\
\hline OVERALL & 2.84 & Agree \\
\hline
\end{tabular}


These perspectives of the science teachers coincide with what Snider (2004) supposed that the spiral Progression approach has advantages and disadvantages. He said that the spiral Progression approach avoids disjunctions between stages of schooling; it allows learners to learn topics and skills appropriate to their developmental/cognitive stages, and it strengthens retention \& mastery of topics \& skills as they are revisited \& consolidated but the problem with the spiral design is that the rate for introducing new concepts is often either too fast or too slow. Similarly, Cobern et al. (2014) stated that a critical aspect of teacher education is gaining pedagogical content knowledge of how to teach science for conceptual understanding. Also, understanding of the curriculum is a teacher's responsibility as Crawford (2000) expressed that in teaching science, especially in an inquiry-based classroom, teachers assume the roles of a motivator, diagnostician, guide, innovator, experimenter, researcher, modeler, mentor, collaborator, as well as a learner.

\section{What is the progress of the students as measured by their grade 10 individual grade average in Science for School Year 2017 - 2018?}

The data presented in table 3 indicates the student respondents' learning progress as measured by their grade 10 individual grade average in science subject for the school year 2017-2018. These were obtained from the grade reports of the students and grading sheets of the science teachers.

Table 3: Overall Students' Progress in Science of the Different Schools

\begin{tabular}{lccl}
\hline Grades & Frequency (F) & Percentage (\%) & Grade Description \\
$90-100$ & 928 & 10.9 & Outstanding \\
$85-89$ & 1715 & 20.1 & Very Satisfactory \\
$80-84$ & 2406 & 28.3 & Satisfactory \\
$75-79$ & 3150 & 37.0 & Fairly Satisfactory \\
74 and below & 314 & 3.7 & Did Not Meet Expectation
\end{tabular}

Total 8513 100.0

Table 3 displays that $37.0 \%$ (3150 student respondents) of the grade 10 students have "fairly satisfactory" performance, followed by "satisfactory" (28.3\%, 2406 student respondents), then "very satisfactory" (20.1\%, 1715 student respondents), "outstanding" (10.9\%, 928 student respondents) and lastly "did not meet expectation" with 3.7\% (314 student respondents). Results revealed in the data imply that there were still a lesser number of students who have "outstanding" performance and "very satisfactory" performance compared to the total number of students who have performances classified as "satisfactory", "fairly satisfactory" and "did not meet expectation". This suggests that the result still conforms to the findings of the Department of Education (DepEd) and Commission on Higher Education (CHED) together with some representatives from private sectors who made an evaluation study on evaluation of basic education program of the country, and found out that the country's basic mathematics and science education is at alarming stage (Lumaque, Sarraga \& Jumawan, 2005). Also, based on the United Nations Development Report 2009, the Philippines is among the countries in the world with a higher literacy rate at 93.4 percent in 2008 but the performance of Filipino students in 
international Mathematics and Science tests stuck at the bottom while struggling at a passing level locally (Ombra, 2016).

With its maiden implementation, fixed results have yet to come if the new $\mathrm{K}$ to 12 curricula will help improve the science performance of Filipino students. In the Philippine $K$ to 12 Curriculum Guide of Science 2013, it states that the goal of the science curriculum is to produce scientifically literate citizens who are informed and active participants of the society, responsible decision-makers, and apply scientific knowledge that will significantly impact the society and the environment.

\section{What are the factors that influence the students' progress in the Science Spiral Progression Curriculum?}

The following results below focus on the factors that influence students' progress in the science spiral progression curriculum as answered by the science teachers. It is divided into three factors namely, student factor, teacher factor, and school factor. In each factor, it is likewise divided into three variables. First, variables under the student factor are learning style, study habits, and motivation to learn. Second, variables under the teacher factor are teachers' specialization, teacher training, and teaching style. Lastly, variables under the school factor are school facilities, learning materials, and support for teacher training.

\section{Student Factor as to Learning Styles}

Table 4: Weighted Means of the Factors Affecting Students' Progress as to Learning Styles

\begin{tabular}{|l|c|c|}
\hline \multicolumn{1}{|c|}{ Items } & $\begin{array}{c}\text { Weighted } \\
\text { Mean }\end{array}$ & $\begin{array}{c}\text { Verbal } \\
\text { Interpretation }\end{array}$ \\
\hline $\begin{array}{l}\text { 1. Students read their notes and the course reading over and } \\
\text { over again. }\end{array}$ & 2.84 & Agree \\
$\begin{array}{l}\text { 2. Students memorize keywords to remind them of important } \\
\text { concepts in the class. }\end{array}$ & 2.91 & Agree \\
$\begin{array}{l}\text { 3. Students to make a list of important terms for the course and } \\
\text { memorize the lists. }\end{array}$ & 2.82 & Agree \\
$\begin{array}{l}\text { 4. Students pull together information from different sources, } \\
\text { such as lectures, readings, and discussions. }\end{array}$ & 2.92 & Agree \\
$\begin{array}{l}\text { 5. Students to write summaries of the main ideas from readings } \\
\text { and the concepts from the lectures. } \\
\text { 6. Students to make simple charts, diagrams, or tables to help } \\
\text { them organize course materials. } \\
\text { 7. Students find themselves questioning things that they hear or } \\
\text { read in the subject to decide if they find it convincing. } \\
\text { 8. Students to play around with ideas of their own related to } \\
\text { what they are learning in the subject. }\end{array}$ & 2.93 & 3.04 \\
$\begin{array}{l}\text { 9. Students to apply ideas from course readings in other class } \\
\text { activities such as lectures and discussion. } \\
\text { 10. Students study the subject in a way that they try to go over } \\
\text { their class notes and make an outline of important concepts. }\end{array}$ & 3.00 & Agree \\
\hline OVERAL & 2.91 & Agree \\
\hline
\end{tabular}

Based on the findings in table 4, the overall weighted mean for all the selected public junior high school in terms of student factor as to learning styles was 2.94 with a verbal interpretation of 
"agree". Individually, Santolan High School (SHS) got a weighted mean of 2.74 (agree), Nagpayong High School (NHS) got 3.27 (strongly agree), Manggahan High School (MHS) got 3.23 (agree), Sta. Lucia High School (SLHS) got 2.86 (agree), Pinagbuhatan High School (PHS) got 2.82 (agree), Rizal High School (RHS) got 2.99 (agree), Rizal Experimental Station and Pilot School of Cottage Industries (RESPCI) got 2.98 (agree), San Joaquin Kalawaan High School (SJHS) got 3.77 (strongly agree), Eusebio High School (EHS) got 2.74 (agree), and Sagad High School (SGHS) got 2.99 (agree). With an overall weighted mean of 2.82 (agree) item 3 (students to make a list of important terms for the course and memorize the lists) got the lowest, while with an overall weighted mean of 3.04 (agree), item 6 (students to make simple charts, diagrams, or tables to help them organize course materials got the highest. This conforms to what the Common Core State Standards (CCSS ELA) believed, that English and language arts teachers share the responsibility with other educators for teaching students to understand "informational text," including science material found in books, magazines, and newspapers, and on the web (NGAC and CCSSO 2010). They added that a picture, a graph can be worth a thousand words. However, almost all students need teachers' help, over a period of years, to read graphs well. In that sense, graph literacy is like learning to read graphs well. In that sense, graph literacy is like learning to read text; each requires repeated practice and a focus on greater complexity as students develop their skills.

\section{Student Factor as to Study Habits}

Table 5: Weighted Means of the Factors Affecting Students' Progress as to Study Habits

\begin{tabular}{|c|c|c|}
\hline Items & $\begin{array}{c}\text { Weighted } \\
\text { Mean }\end{array}$ & $\begin{array}{c}\text { Verbal } \\
\text { Interpretation }\end{array}$ \\
\hline 1. Students read books other than textbooks. & 2.84 & Agree \\
\hline 2. Students to proactively participate during group work. & 3.09 & Agree \\
\hline 3. Students to do their assignments diligently. & 2.80 & Agree \\
\hline $\begin{array}{l}\text { 4. Students break down major concepts into smaller } \\
\text { concepts. }\end{array}$ & 2.89 & Agree \\
\hline $\begin{array}{l}\text { 5. Students learn better when given more complicated } \\
\text { examples. }\end{array}$ & 2.92 & Agree \\
\hline 6. Students take notes during classes. & 3.01 & Agree \\
\hline $\begin{array}{l}\text { 7. Students to study by following strictly the teachers' } \\
\text { instructions. }\end{array}$ & 2.93 & Agree \\
\hline 8. Students memorize the concepts as much as possible. & 2.94 & Agree \\
\hline 9. Students to ask questions. & 3.06 & Agree \\
\hline $\begin{array}{l}\text { 10. Students use different methods from what they learned } \\
\text { at school to solve problems. }\end{array}$ & 3.01 & Agree \\
\hline OVERALL & 2.95 & AGREE \\
\hline
\end{tabular}

Table 5 reveals that generally the science teachers "agree" with an overall weighted mean of 2.95 on the items presented to them in the questionnaire in terms of the factors that affect students' progress as to study habits. With a weighted mean of 3.09, item 2 got the highest; it denotes that participating proactively during group work affect students' progress relative to the execution of the spiral Progression curriculum. With progressivism as one of the basic theories encapsulated in the K to 12 curricula, thus, group work or practical works would help students to learn science. Johnson, Johnson, and Holubec (2008) conveyed that many teachers 
from disciplines across the academe use group work to enhance their students' learning. Whether the goal is to increase student understanding of content, to build transferable skills, or some combination of the two, instructors often turn to small group work to capitalize on the benefits of peer-to-peer instruction. Accordingly, Johnson, Johnson, and Smith performed a meta-analysis of 168 studies comparing cooperative learning to competitive learning and individualistic learning in college students (Johnson, Johnson and Smith, 2014) and they found that cooperative learning produced greater academic achievement than both competitive learning and individualistic learning across the studies.

Item 3 in table 5 deals with students doing their assignment got the lowest weighted mean with 2.80. This means that there is a lesser likelihood that the science teachers "agree" that assignments could be a factor that affects students' progress. This conforms also to the Department of Education's memorandum encouraging teachers to lessen the assignments given to students, which according to Cooper, Robinson, and Patall (2006), that while assigning homework may have academic benefits, it can also cut into important personal and family time. Accordingly, Fernandez, Suarez, and Muniz (2015) in their research revealed that assigning too much homework can result in poor performance. On a lighter note, Darling-Hammond \& IfillLynch (2006) stated that the goal should not be to eliminate homework but to make it authentic, meaningful, and engaging.

Student Factor as to Students' Motivation to Learn

Table 6: Weighted Means of the Factors Affecting Students' Progress as to Motivation to Learn

\begin{tabular}{|c|c|c|}
\hline Items & $\begin{array}{l}\text { Weighted } \\
\text { Mean }\end{array}$ & $\begin{array}{c}\text { Verbal } \\
\text { Interpretation }\end{array}$ \\
\hline $\begin{array}{l}\text { 1. Use course materials that challenge the students so that } \\
\text { they can learn new things. }\end{array}$ & 3.13 & Agree \\
\hline $\begin{array}{l}\text { 2. Make students think that what they will learn in the subject } \\
\text { could be used to understand other subjects. }\end{array}$ & 3.17 & Agree \\
\hline $\begin{array}{l}\text { 3. Make students realize that getting good grades in the } \\
\text { subject is the most satisfying thing for them. }\end{array}$ & 3.09 & Agree \\
\hline $\begin{array}{l}\text { 4. Let students be confident that they can learn the basic } \\
\text { concepts taught in the course. }\end{array}$ & 3.11 & Agree \\
\hline $\begin{array}{l}\text { 5. Use course material that can arouse their curiosity, even if } \\
\text { the subject is difficult to learn. }\end{array}$ & 3.13 & Agree \\
\hline $\begin{array}{l}\text { 6. Make Students realize that the most satisfying thing for the } \\
\text { students is to try to understand the content of the subject as } \\
\text { thoroughly as possible. }\end{array}$ & 3.13 & Agree \\
\hline $\begin{array}{l}\text { 7. Encourage students that they can master the skills being } \\
\text { taught in the subject. }\end{array}$ & 3.16 & Agree \\
\hline $\begin{array}{l}\text { 8. Make students participate in class because they need to } \\
\text { show their abilities, to their families, friends, and others. }\end{array}$ & 3.14 & Agree \\
\hline $\begin{array}{l}\text { 9. Make students think that the course materials on the } \\
\text { subject are useful for them to learn. }\end{array}$ & 3.17 & Agree \\
\hline $\begin{array}{l}\text { 10. Make the students feel confident that they can understand } \\
\text { the most complex material presented by the teacher of the } \\
\text { subject. }\end{array}$ & 3.19 & Agree \\
\hline OVERALL & 3.14 & AGREE \\
\hline
\end{tabular}


Exhibited in table 6 that generally the science teachers "agree" with an overall weighted mean of 3.14 on the items presented to them in the questionnaire in terms of the factors that affect students' progress as to motivation to learn.

Item 10 of table 6 talks about making students feel confident that they understand the most complex material presented by the teacher of the subject got the highest weighted mean of 3.19. This implies that because of the complexity of topics in the progression as it progressed, teachers must have the ability to motivate students to make them believe that they can still understand the lessons presented to them. Delong and Dale (2002) indicated that intrinsic motivation can be long-lasting and self-sustaining. Efforts to build this kind of motivation are also typically efforts at promoting student learning. Such efforts often focus on the subject rather than on rewards or punishments. With the lowest weighted mean of 3.09, there is much less possibility that the science teacher "agree" on item 3, which talks about making students realize that getting good grades in the subject is the most satisfying thing. However, Kumar, Gheen, and Kaplan (2002) argue that performance goals can potentially lead to academic struggle. Similarly, Midgley (2002) points out that the promotion of mastery goals over the school years decreases that the learning process and quality of learning are at risk when grades are used as a motivating force.

\section{Teacher Factor as to Teachers' Specialization}

Table 7: Weighted Means of the Factors Affecting Students' Progress as to Teachers' Specialization

\begin{tabular}{|l|c|c|}
\hline \multicolumn{1}{|c|}{ Items } & $\begin{array}{c}\text { Weighted } \\
\text { Mean }\end{array}$ & $\begin{array}{c}\text { Verbal } \\
\text { Interpretation }\end{array}$ \\
\hline $\begin{array}{l}\text { 1. Preparing students for examinations. } \\
\text { 2. Giving students a positive outlook on the content that I'm } \\
\text { teaching. }\end{array}$ & 3.21 & $\begin{array}{l}\text { Agree } \\
\text { Agree }\end{array}$ \\
$\begin{array}{l}\text { 3. Choosing the right or appropriate outside readings and } \\
\text { materials. }\end{array}$ & 3.08 & Agree \\
$\begin{array}{l}\text { 4. Changing the mindset of the learners to jump to the next } \\
\text { topic. }\end{array}$ & 3.04 & Agree \\
$\begin{array}{l}\text { 5. Changing the nature of the concept of the topic at hand based } \\
\text { on recent discoveries or recent developments in science. } \\
\text { 6. In creating a rubric that can be used effectively to assess the } \\
\text { students. }\end{array}$ & 3.07 & Agree \\
$\begin{array}{l}\text { 7. Managing the time devoted to a particular topic. } \\
\text { 8. Tailoring class plans, activities, and scientific language for } \\
\text { students to understand me better. }\end{array}$ & 3.01 & Agree \\
$\begin{array}{l}\text { 9. Motivating me to teach the topic. } \\
\text { 10. Keeping students on task in the classroom and sparking their } \\
\text { imaginations. }\end{array}$ & 3.06 & Agree \\
\hline OVERALL & 3.01 & Agree \\
\hline
\end{tabular}

Table 7 shows largely that the science teachers "agree" with an overall weighted mean of 3.09 on the items presented to them in the questionnaire in terms of the factors that affect students' progress as to teachers' specialization. With a weighted mean of 3.21 item 1 of table 7 got the highest. The statement focuses on the difficulty of teachers in preparing students for the examination. This may be due to a more sophisticated process of assessment processes under the $\mathrm{K}$ to 12 curricula as assessment in the $\mathrm{K}-12$ curriculum is also standards-based as it seeks to 
ensure that teachers will teach to the standards. The students' attainment of standards in terms of content and performance is, therefore, a critical evidence of learning (DepEd Order No. 31, 2012). Tordecillas (2014) as cited by Orbe, Espinoza, and Datukan (2018) reported that K-12 teachers should understand the standards-based assessment and all other terminologies connected to it. Further, they must have a positive view of it. However, understanding the concept and having a positive perception of it does not guarantee teachers' ease where the construction of the assessment is concerned. Items 6 and 10 got the lowest weighted mean of 3.01. This implies that the science teacher respondents were less likely to "agree" that they have difficulty in creating a rubric that can be used effectively to assess the students and keeping students on task in the classroom and sparking their imaginations.

This implies that science teachers are good at making rubrics to effectively assess their students. This might be because even before the implementation of the $\mathrm{K}$ to 12 science spiral progression curriculum, they are already used to using rubrics as a way to assess their students. According to Glickman-Bond and Rose (2006) apart from being considered as an 'effective' tool for measuring, evaluating, and reporting student achievement, rubrics are also 'designed' to guide students' learning, teachers' instruction, course development, and administrators' program observations. Rubrics, therefore, are held as being direct assessment measures which help to answer the key questions driving outcomes assessment, i.e. "how students learn; what students learn; how is student learning assessed; and how are assessment results used" (Glenn, 2005).

\section{Teacher Factor as to Support for Teacher Training}

Table 8: Weighted Means of the Factors Affecting Students' Progress as to Teachers' Training

\begin{tabular}{|l|c|c|}
\hline \multicolumn{1}{|c|}{ Items } & $\begin{array}{c}\text { Weighted } \\
\text { Mean }\end{array}$ & $\begin{array}{c}\text { Verbal } \\
\text { Interpretation }\end{array}$ \\
\hline 1. Adequate and serious in-service pieces of training on the & 3.07 & Agree \\
curriculum. & 3.07 & Agree \\
2. Equal available professional development opportunities. & 2.85 & Agree \\
3. Available scholarship grants for continuing education. & 2.97 & Agree \\
4. Quarterly in-house professional development in the & 3.10 & Agree \\
school. & & \\
5. Faculty mentoring program for the out of field subjects & & \\
being taught in the curriculum & 3.09 & AGREE \\
\hline OVERALL & & \\
\hline
\end{tabular}

As shown table 8 , essentially the science teachers "agree" with an overall weighted mean of 3.01 on the items presented to them in the questionnaire in terms of the factors that affect students' progress as to teachers' training. Item 5 in this table got the highest weighted mean of 3.10. Science teacher respondents are more likely to "agree" that the new science curriculum demands them to have a faculty mentoring program for the out of field subjects being taught by them in the curriculum. This might be because, in the case of the new curriculum, the specialized subjects are merged into one level. This means that in each grade level, students will take the four basic science disciplines, namely Earth Science, Biology, Chemistry, and Physics in a spiral Progression manner. This implies that science teachers will now teach the four basic disciplines even though it's not their area of specialization. Science teachers cannot escape this 
new challenge because the basic concept of this curriculum is to emphasize the understanding and application of scientific knowledge, learning scientific inquiry skills, and developing and demonstrating scientific attitudes and beliefs (Science Framework for Philippine Basic Education: DOST, 2011).

With the lowest weighted mean of 2.85 is item 3, this implies that there is a much lesser possibility that the science teacher will "agree" that the curriculum demands them to have available scholarship grants for continuing education. Witnessing the latest trend in continuing education, teachers now are aware of the importance of getting a higher degree whether it is for professional and personal growth or promotion. It is now an initiative coming from the teachers because of the stiff competition in the academic world, thus, they now go to graduate schools with or without a scholarship program.

\section{Teacher Factor as to Teaching Styles}

Table 9: Weighted Means of the Factors Affecting Students' Progress as to Teaching Styles

\begin{tabular}{|l|c|c|}
\hline \multicolumn{1}{|c|}{ Items } & $\begin{array}{c}\text { Weighted } \\
\text { Mean }\end{array}$ & $\begin{array}{c}\text { Verbal } \\
\text { Interpretation }\end{array}$ \\
\hline 1. Communicate clearly with your students. & 3.20 & Agree \\
2. Use science materials that are easy to understand. & 3.16 & Agree \\
3. Present the lesson in a variety of ways. & 3.15 & Agree \\
4. Give feedback to students about what should be done & 3.13 & Agree \\
from time to time. & 3.12 & Agree \\
5. Adapt learning experiences to the learners according to & & \\
their developmental level. & 3.15 & Agree \\
6. Maintain eye contact to all corners of the room. & 3.20 & Agree \\
7. Adopt a reasonable and adjustable pace that balances & 3.22 & Agree \\
content coverage and student understanding. & 3.19 & Agree \\
8. Make connections of the topics to current events and & Agree \\
everyday phenomena. & 3.19 & AGREE \\
9. Move around, but not so much that of a distraction. & 3.17 & \\
10. Avoid direct repetition of material in a textbook so that it & & \\
remains a useful alternative resource. & & \\
\hline OVERALL & &
\end{tabular}

It is revealed in table 9 that fundamentally the science teachers "agree" with an overall weighted mean of 3.17 on the items presented to them in the questionnaire in terms of the factors that affect students' progress as to teaching styles. Correspondingly, Datu (2016) said that the curriculum aims to develop learners who are armed with sufficient competencies which could be achieved by actively applying and utilizing it in the real world, actively testing ideas or concepts learned. 


\section{School Factor as to School Facilities}

Table 10: Weighted Means of the Factors Affecting Students' Progress as to School Facilities

\begin{tabular}{|l|c|c|}
\hline \multicolumn{1}{|c|}{ Items } & $\begin{array}{c}\text { Weighted } \\
\text { Mean }\end{array}$ & $\begin{array}{c}\text { Verbal } \\
\text { Interpretation }\end{array}$ \\
\hline $\begin{array}{l}\text { 1. The overall design of the school in terms of aesthetic } \\
\text { values for learning and appropriateness for the age of the } \\
\text { students. }\end{array}$ & 3.06 & Agree \\
$\begin{array}{l}\text { 2. Exterior noise and surrounding environment should not } \\
\text { disrupt classes. }\end{array}$ & 3.20 & Agree \\
$\begin{array}{l}\text { 3. The site and the building should be well landscape. } \\
\text { 4. The location of the facilities should enhance the learning } \\
\text { climate of the school. }\end{array}$ & 3.15 & Agree \\
$\begin{array}{l}\text { 5. Floor plans should direct student movement and minimize } \\
\text { student disruptions } \\
\text { 6. The lighting system that provides proper intensity, } \\
\text { diffusion, and distribution of illumination. }\end{array}$ & 3.23 & Agree \\
$\begin{array}{l}\text { 7. Sound control of the classroom that can provide a } \\
\text { balanced distribution of sound. }\end{array}$ & 3.22 & Agree \\
$\begin{array}{l}\text { 8. Classroom windows that the passage of air so that } \\
\text { students wouldn't be feeling being choke. } \\
\text { 9. Classroom and laboratory furniture that is functionally } \\
\text { sound and facially attractive. }\end{array}$ & 3.22 & Agree \\
$\begin{array}{l}\text { 10. School facilities are both excellent cosmetically and } \\
\text { structurally. }\end{array}$ & 3.27 & Agree \\
\hline OVERALL & 3.20 & Agree \\
\hline
\end{tabular}

It is disclosed in table 10 that primarily the science teachers "agree" with an overall weighted mean of 3.20 on the items presented to them in the questionnaire in terms of the factors that affect students' progress as to school facilities. Largely, the science teachers agree that classroom and laboratory furniture that is functionally sound and facially attractive influences students' progress, as this is the item that garnered the highest weighted mean of 3.20. This might be because, in teaching science, the laboratory is one of the basic needs of students to learn the concepts in science in a real-world scenario. Hofstein and Mamlok-Naaman (2007) state that laboratory experiences have been given a central role in science education. Many benefits are said to come from engaging students in laboratory activities.

Item 1 in table 10 got the lowest weighted mean of 3.06. The lesser likelihood exists in this item that science teachers would agree that the overall design of a school in terms of aesthetic values for learning and appropriateness for the age of the students. This implies that science teachers believe that the overall aesthetic of the school is not much of a concern, as long as the school is clean and peaceful, and students can learn the lessons in the best possible way. Also, this might be because schools in the Philippines are built not by age level but by the design appropriate for the whole grade levels, notwithstanding the political intervention of the politicians. 


\section{School Factor as to Learning Materials}

Table 11: Weighted Means of the Factors Affecting Students' Progress as to Learning Materials

\begin{tabular}{|l|c|c|}
\hline \multicolumn{1}{|c|}{ Items } & $\begin{array}{c}\text { Weighted } \\
\text { Mean }\end{array}$ & $\begin{array}{c}\text { Verbal } \\
\text { Interpretation }\end{array}$ \\
\hline $\begin{array}{l}\text { 1. Capacity and resources in the library are adequate for the } \\
\text { number of students in the school. }\end{array}$ & 3.04 & Agree \\
$\begin{array}{l}\text { 2. Adequacy of tables and chairs in the classroom. } \\
\text { 3. Adequacy of equipment in the laboratory to be used in } \\
\text { teaching science concepts. }\end{array}$ & 3.08 & Agree \\
$\begin{array}{l}\text { 4. Sufficiency of the number of teachers' guides in the } \\
\text { school. }\end{array}$ & 3.12 & Agree \\
$\begin{array}{l}\text { 5. Availability of resources such as manila papers, chalk, } \\
\text { models, charts, and other teaching paraphernalia. }\end{array}$ & 3.19 & Agree \\
$\begin{array}{l}\text { 6. The use of field trips/excursions in the school to explore } \\
\text { science concepts. }\end{array}$ & 2.99 & Agree \\
$\begin{array}{l}\text { 7. Availability of teaching soft wares in science and the use of } \\
\text { computers in teaching and learning science concepts. } \\
\text { 8. The rigidity of procedures of acquiring the materials for } \\
\text { learning. }\end{array}$ & 3.09 & Agree \\
9. Adequacy of books given to every student. & 3.08 & Agree \\
$\begin{array}{l}\text { 10. Sufficiency of visual resources such as videos, PowerPoint } \\
\text { presentations, and the like in teaching science concepts. }\end{array}$ & 3.18 & Agree \\
\hline OVERALL & 3.11 & Agree \\
\hline
\end{tabular}

Table 11 reveals that predominantly the science teachers "agree" with an overall weighted mean of 3.11 on items presented to them in the questionnaire in terms of the factors that affect students' progress as to learning materials.

With a weighted mean of 3.22, item 9 in table 11 got the highest. More likely, the teachers would agree that the adequacy of books given to every student influences their progress. This issue must have come into place because, in the Philippines, students were not given the chance to have a one is to one supply of textbooks. Critics in the Philippines suggest that this issue stem from the government's propensity to address shortages of inputs-through new classroom construction, teacher hiring, and textbook procurement-rather than focus on root causes of the underperformance, such as weak governance, political discontinuity, and lack of accountability (PIDS, 2009). Item 6 got the lowest weighted mean of 2.99, which implies that there is a lesser likelihood that the science teachers agree that the use of field trips/excursions in the school to explore science concepts influences students' progress. This might be because science teachers believed that mastery of science concepts can be done already in the school as long as there is an adequacy of materials needed in teaching the subject and there is the availability of laboratory to perform experimental activities in teaching the subject. However, Behrendt and Franklin (2014) have a different perspective; they said that effective methods to develop student interest include experiential activities and field trips, which create authentic learning opportunities for students, regardless of the content area. Also, Lei (2010) argues that field trips take students to locations that are unique and cannot be duplicated in the classroom. Each student observes natural settings and creates personally relevant meaning to the 
experience. Interactive exhibits help students play with concepts, activities often not possible in the classroom.

\section{School Factor as to Support to Teacher Training}

Table 12: Weighted Means of the Factors Affecting Students' Progress as to Support to Teacher Training

\begin{tabular}{|c|c|c|}
\hline Items & $\begin{array}{l}\text { Weighted } \\
\text { Mean }\end{array}$ & $\begin{array}{c}\text { Verbal } \\
\text { Interpretation }\end{array}$ \\
\hline $\begin{array}{l}\text { 1. Having a training and development policy applicable to all } \\
\text { teachers. }\end{array}$ & 3.24 & Agree \\
\hline $\begin{array}{l}\text { 2. Intensifying echoing program of seminars and training } \\
\text { attended. }\end{array}$ & 3.26 & Strongly Agree \\
\hline $\begin{array}{l}\text { 3. Intensifying linkage in from stakeholders for training and } \\
\text { development. }\end{array}$ & 3.26 & Strongly Agree \\
\hline $\begin{array}{l}\text { 4. A full-fledged training and development department in } \\
\text { the school must be built and must be manned with } \\
\text { competent professionals. }\end{array}$ & 3.40 & Strongly Agree \\
\hline $\begin{array}{l}\text { 5. Coordinators help teachers set realistic goals for } \\
\text { performing their work as a result of their training. }\end{array}$ & 3.27 & Strongly Agree \\
\hline $\begin{array}{l}\text { 6. Schools make sure that teachers have the opportunity to } \\
\text { use their training immediately. }\end{array}$ & 3.24 & Agree \\
\hline $\begin{array}{l}\text { 7. Schools must make it a point that the equipment used in } \\
\text { training is similar to the equipment found in real teaching } \\
\text { scenarios. }\end{array}$ & 3.29 & Strongly Agree \\
\hline $\begin{array}{l}\text { 8. Teachers who use their training are given preference for } \\
\text { new assignments. }\end{array}$ & 3.30 & Strongly Agree \\
\hline OVERALL & 3.28 & $\begin{array}{l}\text { Strongly } \\
\text { Agree }\end{array}$ \\
\hline
\end{tabular}

It is disclosed in table 12 that chiefly the science teachers "agree" with an overall weighted mean of 3.28 on the items presented to them in the questionnaire in terms of the factors that affect students' progress as to support teacher training. With a weighted mean of 3.40 , item 4 got the highest. There is a great agreement from the science teachers that a full-fledged training and development department in the school must be built and must be manned with competent professionals that influences students' progress. Studies have shown that 'teacher quality' is the single most important school-level variable influencing student achievement (OECD, 2005). Recognition of the importance of teachers to student outcomes has resulted in a shift in aid investment from a primary focus on increasing access to education to increasing support for interventions aimed at improving teacher quality in developing countries (Colclough, 2005). Also, a recent review of 20 high-quality studies measuring the impact of teacher quality in developing countries found that teachers when subjected to knowledge training was strongly related to student learning (Glewwe, Hanushek, Humpage \& Ravina, 2011). 


\section{CONCLUSIONS}

Based on the findings from this study, the following conclusions were drawn: (1) The perspectives of the science teachers foster a positive understanding of the science spiral progression curriculum as to the content, strategies, and confidence in implementing the curriculum; (2) The public junior high school grade ten students of Pasig City profess "fairly satisfactory" academic performance or progress in science; and (3) There are many factors that may influence students' learning progress in the science spiral progression curriculum as seen in the results of this research.

\section{RECOMMENDATIONS}

The following recommendations are drawn based on the findings of the study: (1) The Department of Education of the Philippines and its implementing arms may integrate plans in providing more concrete programs to support teachers' training in relation to the science spiral progression curriculum; (2) Principals in the public junior high schools may develop motivational plans that would encourage science teachers to continue to learn and to persuade graduate studies to enhance their knowledge on the disciplines of science that are not their area of specialization; (3) Principals in the public junior high schools may devise concrete and serious faculty development programs to be conducted as timely as possible not only on strategies on how to teach the science spiral progression curriculum but also the understanding of the content of each discipline in the science curriculum for the benefit of the science teachers who are teaching the science disciplines which are not their area of specialization; (4) Administration of each public junior high school may establish school-based training or cluster-based training program if there are financial constraints in sending teachers to big training events; (5) School administrators in the Department of Education may revisit the implementation of the science spiral progression curriculum and this research may guide them to trace immediate problems regarding the implementation of the curriculum; (6) Future researchers may conduct future researches in relation with this research on the following aspects: (a) effects of the scheme of implementation (disciplinal or not disciplinal) of the science spiral progression curriculum in the academic performance of the students (b) phenomenological plight that teachers are experiencing on executing the spiral progression curriculum (c) students' progress focusing on the individual disciplines in the science progression and (d) correlates of the academic performance of students in science in terms of their demographic profiles. 


\section{REFERENCES}

Behrendt, M., \& Franklin, T. (2014). A Review of Research on School Field Trips and their Value in Education. International Journal of Environmental and Science Education. Retrieved from http://doi.org/10.12973/ijese.2014.213a

Brameld, T. (1956). Toward a reconstructed philosophy of education. New York: Dryden. Burila, JM (2012). K to 12 Education in the Philippines: For Better or for Worse? Retrieved from http://www.academia.edu/6937076/K12 Education in the Philippines For the bette $r$ or for worse Critique Paper.

Cobern, W. W., Schuster, D., Adams, B., Skjold, B. A., Muğaloǧlu, E. Z., Bentz, A., \& Sparks, K. (2014). Pedagogy of Science Teaching Tests: Formative Assessments of Science Teaching Orientations. International Journal of Science Education, 36(13), 2265-2288. DOI:10.1080/09500693.2014.918672.

Colclough C. (2005). Prospects for Achieving Education for All. ZEP: Zeitschrift Für Internationale Bildungsforschung und Entwicklungspädagogik.

Cooper, H., Robinson, J. C., \& Patall, E. A. (2006). Does Homework Improve Academic Achievement? A Synthesis of Research, 1987-2003. Review of Educational Research, 76(1), 1-62.

Crawford, B.A. (2000). Embracing the Essence of inquiry: New Roles for Science Teachers. Journal of Research in Science Teaching, 37, 916-937.

Creswell, J. W. (2012). Qualitative Inquiry and Research Design: Choosing Among Five Approaches (4th ed.). Thousand Oaks, CA: Sage.

Darling-Hammond, L., \& Ifill-Lynch, O. (2006). "If They'd Only Do Their Work!". Educational Leadership, 63(5), 8-13.

Datu, N. (2016). The Philosophical Bases of the K to 12 Curriculum. Pampanga, Philippines: SunStar Publishing.

DeLong M. and Winter D. (2002). Learning to Teach and Teaching to Learn Mathematics: Resources for Professional Development. USA: Mathematical Association of America.

DepEd Order No. 8 Series of 2015, "Policy Guidelines on Classroom Assessment for the K to 12 Basic Education Program." Pasig City, Philippines: Department of Education.

DepEd Order 31 s. 2012 "Policy Guidelines on the Implementation of the Grade 1 to 10 of the K to12 Basic Education Curriculum (BEC) Effective School Year 2012-2013." Pasig City, Philippines: Department of Education.

Department of Education. (2010). “Discussion Paper on the Enhanced K + 12 Basic Education Program". Pasig City, Philippines: Department of Education.

Elliott, S.N., Kratochwill, T.R., Littlefield Cook, J., and Travers, J. (2000). Educational psychology: Effective teaching, effective learning (3rd ed.). Boston, MA: McGraw-Hill College. 
Estolas, J., and Macaballug J. (1995). Fundamentals of Research, Revised Edition. Manila, Philippines: Miranda Bookstore.

Fernández-Alonso, R., Suárez-Álvarez, J., \& Muñiz, J. (2015). Adolescents' Homework Performance in Mathematics and Science: Personal Factors and Teaching Practices. Journal of Educational Psychology. Advance Online Publication.

Glenn, C. (2005). "Outcomes Assessment in Higher Education: Using Assessment Instruments to Improve Business Curriculum and Instruction at the Association of Collegiate Business Schools and Programs (ACBSP)." Thesis, Philadelphia, PA: Saint Joseph's University.

Glewwe, P. W., E. A. Hanushek, S. D. Humpage, and R. Ravina. (2011). "School Resources and Educational Outcomes in Developing Countries: A Review of the Literature from 1990 to 2010" In Education Policy in Developing Countries. Chicago: University of Chicago Press.

Glickman-Bond, J. and Rose, K. (2006) Creating and Using Rubrics in Today's Classrooms, Norwood, MA: Christopher-Gordon Publishers, Inc.

Hofstein A. and Mamlok-Naaman R. (2007). The Laboratory in Science Education: State of the Art. Chemistry Education Research and Practice.

Hunter Laura and Erin Leahey. (2008). "Collaborative Research in Sociology: Trends and Contributing Factors". American Sociologist.

Johnson, D.W., Johnson, R.T., and Holubec, E.J. (2008). Cooperation in The Classroom (8th edition). Edina, MN: Interaction.

Johnson, D.W., Johnson, R.T., and Smith, K.A. (2014). Cooperative Learning: Improving University Instruction by Basing Practice on Validated Theory. Journal on Excellence in College Teaching 25, 85-118.

K to 12 Curriculum Guide (2013). Pasig City, Philippines: Department of Education.

Kumar, R., Gheen, M. H., and Kaplan, A. (2002). Goal Structures in the Learning Environment and Students' Disaffection from Learning and Schooling. NJ: Erlbaum.

Labaree, D. F. (2000). On the Nature of Teaching and Teacher Education: Difficult Practices that Look Easy. Journal of Teacher Education, 51, 228-233.

Leedy, Paul D., and Ormrod, Jeanne E. (2014). Practical Research and Design. Pearson Publishing.

Lei, S.A. (2010). Assessment Practices of Advanced Field Ecology Courses Education. 130(3), 404415.

Lumaque, L., Sarraga, R. \& Jumawan R. (2005). Preparedness of Secondary School Students in Cotabato City for Science Career. NDU Faculty Research Journal. Vol. 6.

Martin, B. (2008). Obstacles to Academic Integrity. Proceedings of the 3rdrd Asia-Pacific Conference of Educational Integrity: Creating a Culture of Integrity. University of South Australia

Mason, L. (2019). Dewey and Political Communication in the Age of Mediation. Journal of Culture and Values in Education, 2(3), 94-102. https://doi.org/10.46303/jcve.03.02.6 
Mauch, J., \& Tarman, B. (2016). A Historical Approach to Social Studies Laboratory Method. Research in Social Sciences and Technology, 1(2). https://doi.org/10.46303/ressat.01.02.2

Midgley, C. (2002). Goals, Goal Structures, and Patterns of Adaptive Learning. Mahwah, NJ: Erlbaum.

National Governors Association Center for Best Practices and Council of Chief State School Officers (2010). Common Core State Standards in Mathematics and Language Arts. Washington, DC: NGAC and CCSSO.

Organization for Economic Co-operation and Development (OECD), (2005). Teachers Matter: Attracting, Developing, and Retaining Effective Teachers. Retrieved from http://www.oecd.org/education/school/48627229.pdf

Ombra A. Imam. (2016). Effects of Reading Skills on Students' Performance in Science and Mathematics in Public and Private Secondary Schools. Journal of Education and Learning, Vol. 10 (2) pp. 177-186.

Orbe, J. R., Espinosa, A. A., \& Datukan, J. T. (2018). Teaching Chemistry in a Spiral Progression Approach: Lessons from Science Teachers in the Philippines. Australian Journal of Teacher Education, 43(4).

Phillips, D. C. (1995). The Good, the Bad, and the Ugly: The Many Faces of Constructivism. Educational researcher, 24(7), 5-12.

Philippine Institute for Development Studies (PIDS) (2009). Governance in the Education Sector. Development Research News, volume XXVII (No. 4). Makati City, Philippines: Philippine Institute for Development Studies.

Pintrich, P., Smith D., Garcia, T., and McKeachie W.J. (1991). A Manual for the Use of the Motivated Strategies for Learning Questionnaires. Michigan, USA: Ann Arbor National Center for Research to Improve Postsecondary Teaching and Learning.

Science Framework for Philippine Basic Education: Department of Science and Technology (2011). Retrieved from http://www.sei.dost.gov.ph/images/downloads/publ/sei scibasic.pdf

Snider, M. (2004). Do School Facilities Affect Academic Outcomes? Washington DC: National Clearinghouse for Educational Facilities. 